\title{
ANALYSIS OF PRODUCT PREFERENCE OF CHITATO AND LAYS POTATO CHIPS
}

\author{
Rafadi Khan Khayru', Didit Darmawan ${ }^{2}$, Misbachul Munir ${ }^{3^{*}}$ \\ ${ }^{1}$ Airlangga University \\ ${ }^{2}$ Mayjen Sungkono University \\ ${ }^{3 *}$ Sunan Giri University \\ E-mail: miscbahulmunir637@gmail.com
}

\begin{abstract}
This study aims to determine differences in consumer preferences for potato chip products. Two well-known local brands, Chitato and Lays, come from the same manufacturer and it is interesting to observe the differences in consumer preferences for the two. These two brands already have a high level of brand awareness in the market as evidenced by a larger market share than other brands. Samples were taken as many as 94 respondents with a sampling technique with an accidental sampling approach. The results of the questionnaire were analyzed by SPPS statistics in the form of validity and reliability tests, Paired Sample t-test to see the significance of differences in consumer preferences for potato chips products. The results of hypothesis testing indicate that the consumer preferences of the Chitato brand and the Lays brand are not significantly different. According to respondents as consumers, the selection of potato chip products is the same as buying so that it is the task of marketers to strengthen product attributes and the brand strength of each product.
\end{abstract}

Keywords: Potato Chips, Consumer Preferences, Purchasing Decisions.

\section{INTRODUCTION}

Potato chips are thin slices of potato from frying or roasting that have a crunch. This product is categorized as a snack accompanied by a variety of spices to add variety to the taste (Katundu et al., 2010). Many potato chip products have been offered by manufacturers. From large manufacturers to home manufacturers offer this product. Promising market potential has made this product continue to grow to this day. However, wide market coverage and efforts to enter the market require the right marketing strategy (Iskandar \& Darmawan, 2003; Khasanah et al., 2010).

One way to get regular customers from potato chip products is through observing and understanding consumer behavior focused on purchasing decisions for potato chip products. Consumer preferences are the beginning of knowing the segmentation of consumer perceptions of the products offered (Kotler, Philip \& Amstrong, 2016; Mardikaningsih, R. \& Sinambela., 2016; Mardikaningsih \& Putra, 2017). This preference will provide input for producers and form a further offer package as a form of product development (Downes, 2008; Siró et al., 2008; Sveinsdóttir et al., 2009; Urala \& Lähteenmäki, 2004). Knowledge and understanding of consumers in buying potato chip products is needed to select the offer package (Darmawan, 2019; Schiffman \& Kanuk, 2010). However, this consumer behavior 


\section{JOURNAL OF MANAGEMENT, ACCOUNTING, GENERAL FINANCE AND INTERNATIONAL ECONOMIC ISSUES (MARGINAL) \\ VOLUME 1 ISSUE 1 (2021)}

is very difficult to predict because the likes and interests of a product are very difficult to predict (Yanti \& Yuliana, 2018). However, this can be an opportunity if producers can segment consumers into several characteristics (Gunawan et al., 2019; Naylor et al., 2009). These consumer characteristics are the background as well as the opportunity to read the market demand for potato chip products in the target market. Understanding consumer conditions and consumer needs is one of the most important issues in the application of market-oriented marketing (Masitoh et al., 2017; Purnamasari et al., 2002; Sinambela, 2017).

There are many potato chip products circulating in the market, Chitato and Lays are well-known ones that are well known to the public and are always available on the shelves of every snack shop to modern ones such as minimarkets and supermarkets. Are there differences in consumer preferences for the selection of potato chip products? Two wellknown brands, Chitato and Lays, are unique because they are both produced by Indofood. The rivalry between fans of these two potato chip brands is quite fierce in the market, and both have loyalists. The difference that can be seen from this chip is in terms of its wavy shape and one is straight and smooth, the other is thicker while the other is thinner. The rest is individual preference. Even though there is market competition, one manufacture is not a threat to producers (Darmawan, 2010). The two brands actually have to strengthen their respective brand equity in order to be able to win market competition with other manufacturers. Thus, this study aims to determine the differences in consumer preferences for Chitato and Lays brand potato chips.

\section{RESEARCH METHODS}

The type of research used in this research is comparative research, which is research that compares one or more variables in two different samples. This study compares consumer preferences for Chitato and Lays brand potato chips.

The population is a large group and the area that is the scope of research. The population in this study were consumers of Chitato and Lays brand potato chips in the city of Surabaya. The sample is part or the number and characteristics possessed by the population. Researchers distributed questionnaires to 100 respondents by accidental sampling to groups of high school students in the city of Surabaya. The number of questionnaires eligible for further processing was determined as the research sample.

The analytical method used is validity test, reliability test, normality test, Independent Sample t-Test. Experimental research usually uses two or more samples as the object of research. The samples were compared to see if there was a difference after the samples were given different treatments. To see whether there is a difference, a difference test of the two means is carried out. Independent-samples t-test using the variance between the two samples being compared is not significantly different (homogeneous). The data used are from two different samples. The hypothesis of this research is

$\mathrm{H}_{0}$ : There is no significant difference between consumer preferences for Chitato and Lays brand potato chips.

$\mathrm{H}_{1}$ : There is a significant difference between consumer preferences for Chitato and Lays brand potato chips.

\section{RESULTS AND DISCUSSION}




\section{JOURNAL OF MANAGEMENT, ACCOUNTING, GENERAL FINANCE AND INTERNATIONAL ECONOMIC ISSUES (MARGINAL) \\ VOLUME 1 ISSUE 1 (2021)}

From the previous determination of the research method, it has been stated that the study involved 100 questionnaires distributed to prospective respondents, but only 94 were eligible for further processing. The initial stage is to test the validity and test reliability. Validity test is used to measure the validity or validity of a questionnaire. The questionnaire is said to be valid if the questions on the questionnaire are able to reveal something that will be measured by the questionnaire. Reliability test to measure a questionnaire which is an indicator of a variable. A questionnaire is said to be reliable or reliable if a person's answer to the statement is consistent or stable from time to time. The results of the validity and reliability tests are shown in the table.

Table 1 Validity and Reliability Test Results

\begin{tabular}{|c|c|c|c|c|c|c|c|c|}
\hline \multirow[b]{2}{*}{ Variable } & \multirow{2}{*}{ Indicator } & \multirow[b]{2}{*}{ Statement } & \multicolumn{2}{|c|}{ Chitato } & \multicolumn{2}{|c|}{ Lays } & \multirow{2}{*}{$\begin{array}{l}\text { Chitato } \\
\text { Cronbach } \\
\text { Alpha }\end{array}$} & \multirow{2}{*}{$\begin{array}{c}\text { Lays } \\
\begin{array}{c}\text { Cronbach } \\
\text { Alpha }\end{array}\end{array}$} \\
\hline & & & Sig & $\mathbf{R}$ & Sig & $\mathbf{R}$ & & \\
\hline \multirow{9}{*}{$\begin{array}{l}\text { Consumer } \\
\text { Preference }\end{array}$} & \multirow{3}{*}{ Cognitive } & X1.1 & 0.000 & 0.406 & 0.000 & 0.537 & \multirow{3}{*}{0.702} & \multirow{3}{*}{0.698} \\
\hline & & $\mathrm{X} 1.2$ & 0.000 & 0.482 & 0.000 & 0.461 & & \\
\hline & & $\mathrm{X} 1.3$ & 0.000 & 0.435 & 0.000 & 0.557 & & \\
\hline & \multirow{3}{*}{ Affective } & $\mathrm{X} 1.4$ & 0.000 & 0.431 & 0.000 & 0.419 & \multirow{3}{*}{0.713} & \multirow{3}{*}{0.748} \\
\hline & & $\mathrm{X} 1.5$ & 0.000 & 0.425 & 0.000 & 0.306 & & \\
\hline & & $\mathrm{X} 1.6$ & 0.000 & 0.441 & 0.000 & 0.442 & & \\
\hline & \multirow{3}{*}{ Conative } & X1.7 & 0.000 & 0.551 & 0.000 & 0.512 & \multirow{3}{*}{0.708} & \multirow{3}{*}{0.727} \\
\hline & & X1.8 & 0.000 & 0.337 & 0.000 & 0.448 & & \\
\hline & & X1.9 & 0.000 & 0.463 & 0.000 & 0.523 & & \\
\hline
\end{tabular}

Table 1 shows that the significant value for each statement is less than 0.05 , so it can be concluded that each statement is said to be valid. Cronbach's Alpha value for each statement is greater than 0.6 , it can be concluded that each statement is said to be reliable.

Table 2 Normality test results

\begin{tabular}{|c|c|c|}
\hline Variable & Significance & Status \\
\hline Chitato Consumer Preferences & 0.371 & Normal \\
\hline Lays Consumer Preferences & 0.272 & Normal \\
\hline
\end{tabular}

Table 2 shows that Chitato's consumer preference is 0.371 and Lays' consumer preference is 0.272 which has a significance value greater than 0.05 at ( $\operatorname{sig}>0.05)$, so it can be concluded that the research data is normally distributed.

Table 3 Paired Sample t-test

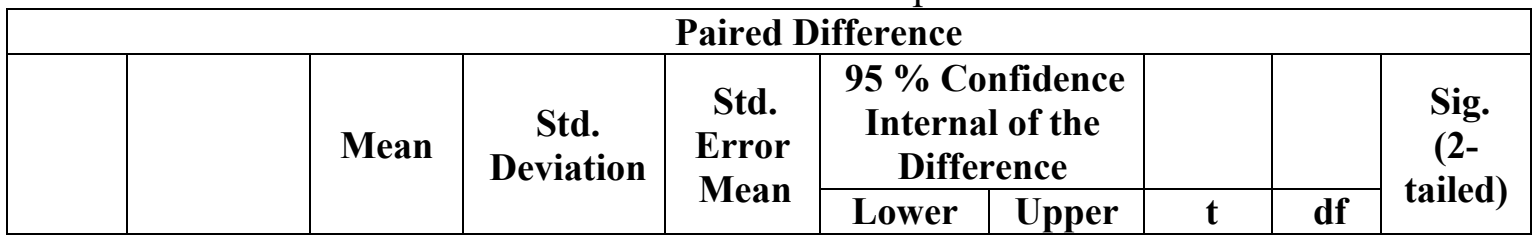




\section{JOURNAL OF MANAGEMENT, ACCOUNTING, GENERAL FINANCE AND INTERNATIONAL ECONOMIC ISSUES (MARGINAL) \\ VOLUME 1 ISSUE 1 (2021)}

\begin{tabular}{|c|c|c|c|c|c|c|c|c|c|}
\hline $\begin{array}{c}\text { Pair } \\
1\end{array}$ & $\begin{array}{c}\text { Chitato- } \\
\text { Lays }\end{array}$ & .17389 & 5.01191 & .24221 & .24950 & .73547 & .707 & 93 & .365 \\
\hline
\end{tabular}

Table 3 shows that the significance value is more than 0.05 , which is 0.365 , meaning that there is an insignificant difference, so it can be concluded that the Chitato brand and Lays brand products are not significantly different based on consumer perceptions. This means that consumer preferences when faced with product choices between Chitato brand and Lays brand crunchy chips are not significantly different in consumer purchasing decisions, especially consumer preferences in product use.

The results showed that the consumer preferences of Chitato brand potato chips and Lays brand were not significantly different. The results of this study, it can be concluded that the two potato chip products have insignificant differences, meaning that consumer preferences for Chitato and Lays brand potato chips are not significantly different in terms of the use of potato chip products. In this case the segmentation formed in the potato chip product market is a homogeneous preference. This form of preference is shown to consumers who have relatively similar preferences in general, even though no in-depth and follow-up observations have been made. This can be useful as a producer's effort to understand the preferences of the target market. From this, producers can then determine appropriate marketing strategies to meet target market expectations and to face real competitors, namely potato chip producers who are different as competitors (Chen, 2011). Consumers need to develop their knowledge about the choice of branded potato chip products. They need to seek more information in order to have knowledge that will support the quality of their decision making in choosing potato chips that suit their preferences (Aschemann-Witzel \& Hamm, 2010). This makes it imperative for manufacturers to strengthen brands, increase product diversity and product attributes that can attract continued purchases (Darmawan, 2021).

\section{CONCLUSION AND SUGGESTIONS}

The conclusion in this study shows that the consumer preferences of Chitato and Lays brand potato chips are not significantly different. According to respondents as consumers, the choice of potato chip products is the same to buy. These findings indicate that the core product in the form of potato chips has succeeded in offering basic benefits. It's just that manufacturers set differentiation based on different shapes, flavors and packaging have not succeeded significantly because the research results show that they are not significantly different. Manufacturers can pay attention to brand strengthening strategies so that brand associations place more emphasis on real brand differentiation even though the basic benefits are the same. Thus, packaging in a radically different form is suggested in order to strengthen the branding of the two. In addition, it adds diversity or product variants to expand consumer preferences for products and brands.

Each target market must view every product produced by the same producer as a set of attributes. Different brands have different attributes but in similar and relevant products. For future research, it is recommended to research other products with other brands that may be better than the product that the researcher uses. 


\section{JOURNAL OF MANAGEMENT, ACCOUNTING, GENERAL FINANCE AND INTERNATIONAL ECONOMIC ISSUES (MARGINAL) \\ VOLUME 1 ISSUE 1 (2021)}

\section{REFERENCES}

Aschemann-Witzel, J., \& Hamm, U. (2010). Do consumers prefer foods with nutrition and health claims? results of a purchase simulation. Journal of Marketing Communications, 16(1-2). https://doi.org/10.1080/13527260903342746

Chen, M. F. (2011). The joint moderating effect of health consciousness and healthy lifestyle on consumers' willingness to use functional foods in Taiwan. Appetite, 57(1). https://doi.org/10.1016/j.appet.2011.05.305

Darmawan, D. (2010). Manajemen Pemasaran. IntiPresindo Pustaka.

Darmawan, D. (2019). The Effect of Corporate Image On Brand Awareness and Brand Attitude. Translitera: Jurnal Kajian Komunikasi Dan Studi Media, 8(01). https://doi.org/10.35457/translitera.v8i01.595

Darmawan, D. (2021). Pencapaian Kepuasan dan Loyalitas Pelanggan melalui Strategi Pemasaran Berdasarkan Pengalaman. Jurnal Manajemen, Bisnis, Dan Kewirausahaan, $1(1), 1-13$.

Downes, L. (2008). Motivators and barriers of a healthy lifestyle scale: Development and psychometric characteristics. Journal of Nursing Measurement, 16(1). https://doi.org/10.1891/1061-3749.16.1.3

Gunawan, A., Arum, S., Mahyanaila, R., \& Khasanah, H. (2019). Perilaku Konsumen dan Pemasaran Strategik. Spektrum Nusa Press.

Iskandar, M., \& Darmawan, D. (2003). Strategi Pemasaran. IntiPresindo Pustaka.

Katundu, M., Hendriks, S., Bower, J., \& Siwela, M. (2010). Can sequential harvesting help small holder organic farmers meet consumer expectations for organic potatoes? Food Quality and Preference, 21(4). https://doi.org/10.1016/j.foodqual.2009.09.003

Khasanah, H., Arum, S., \& Darmawan, D. (2010). Pengantar Manajemen Bisnis. Spektrum Nusa Press.

Kotler, Philip \& Amstrong, G. (2016). Principles of marketing (11 ed.). New York: Pearson International.

Mardikaningsih, R. \& Sinambela., E. A. (2016). Peranan Komunikasi Pemasaran, Citra Merek dan Kepercayaan Merek Terhadap Kesetiaan Merek. Jurnal Ilmu Manajemen, 2(1).

Mardikaningsih, R., \& Putra, A. R. (2017). Analisis Perbandingan Sikap Konsumen terhadap Penggunaan Produk Garam Beryodium Merek Kapal dan Dolpin di Sidoarjo. Jurnal Agrimas, 1(1), 49-54.

Masitoh, D., Darmawan, D., \& Sinambela, E. A. (2017). The Effect of Service Quality and Trust on Customer Loyalty of Warung Apung Rahmawati of Mojokerto Branch. Jurnal AgrimasMasitoh, 1(2), 107-114.

Naylor, R. W., Droms, C. M., \& Haws, K. L. (2009). Eating with a purpose: Consumer response to functional food health claims in conflicting versus complementary information environments. Journal of Public Policy and Marketing, 28(2). https://doi.org/10.1509/jppm.28.2.221

Purnamasari, E., Darmawan, D., \& Baskara, D. (2002). Bauran Pemasaran dan Kualitas Layanan serta Pengaruhnya terhadap Kepuasan dan Loyalitas Pelanggan. Jurnal Ilmu Manajemen, 3, 34-36.

Schiffman, L., \& Kanuk, L. L. (2010). Consumer Behavior 10th Edition. Pearson Education. 


\section{JOURNAL OF MANAGEMENT, ACCOUNTING, GENERAL \\ FINANCE AND INTERNATIONAL ECONOMIC ISSUES \\ (MARGINAL) \\ VOLUME 1 ISSUE 1 (2021)}

Sinambela, E. A. (2017). Pengaruh Ekuitas Merek dan Harga Terhadap Keputusan Pembelian Produk Kopi Kemasan. Jurnal Pemasaran, 1(2).

Siró, I., Kápolna, E., Kápolna, B., \& Lugasi, A. (2008). Functional food. Product development, marketing and consumer acceptance-A review. In Appetite (Vol. 51, Issue 3). https://doi.org/10.1016/j.appet.2008.05.060

Sveinsdóttir, K., Martinsdóttir, E., Green-Petersen, D., Hyldig, G., Schelvis, R., \& Delahunty, C. (2009). Sensory characteristics of different cod products related to consumer preferences and attitudes. Food Quality and Preference, 20(2). https://doi.org/10.1016/j.foodqual.2008.09.002

Urala, N., \& Lähteenmäki, L. (2004). Attitudes behind consumers' willingness to use functional foods. Food Quality and Preference, 15(7-8 SPEC.ISS.). https://doi.org/10.1016/j.foodqual.2004.02.008

Yanti, Y., \& Yuliana. (2018). Manajemen Pemasaran. IntiPresindo Pustaka. 